\title{
Preliminary Assessment of Polycyclic Aromatic Hydrocarbons Associated to Airborne PM10 in Győr, Hungary
}

\author{
A. Szabó Nagy, Zs. Csanádi, J. Szabó \\ Széchenyi István University, Physics and Chemistry Department \\ Egyetem square 1, 9026 Győr, Hungary \\ e-mail: nszaboa@sze.hu
}

Abstract: The aim of this study was to assess the ambient concentrations of polycyclic aromatic hydrocarbons (PAHs) associated to the PM10 aerosol fraction in an urban site of Győr, Hungary in 2011. The levels of total PAHs and the individual compounds show large variability during the sampling periods. The total PAH concentrations ranged from $0.88 \mathrm{ng} / \mathrm{m}^{3}$ to $95.80 \mathrm{ng} / \mathrm{m}^{3}$ with the mean value of $20.06 \mathrm{ng} / \mathrm{m}^{3}$. Four and five-rings PAHs were the dominant species in the samples. The levels of carcinogenic PAH species (benzo[a]pyrene, benz[a]anthracene, sum of the three benzofluoranthene isomers, indeno[1,2,3-c,d]pyrene and dibenz[a,h]anthracene) determined were compared with published data of other Hungarian cities. The potential carcinogenic risks of PAHs were also estimated.

Keywords: polycyclic aromatic hydrocarbons, $P A H s$, ambient air, air quality

\section{Introduction}

Atmospheric aerosols are very important ambient components in point of air quality. Monitoring the particulate matter with an aerodynamic diameter smaller than $10 \mu \mathrm{m}$ (PM10) and PM10-bound polycyclic aromatic hydrocarbons (PAHs) could have important environmental significance and health protection aspects [1].

PAHs are a large group of organic compounds included two or more coupled benzene rings arranged in various configurations. In addition to natural sources they generally derive from the incomplete combustion of organic materials and pyrolysis of hydrocarbons (e.g. coal, petrol, diesel and wood). The main PAH sources are traffic exhausts and industrial emissions, domestic heating and oil refining. Moreover, it is well known that road dust resuspension can contribute to fine aerosols especially during dry weather conditions. It is suggested that road dust may be a significant source of particlebound PAHs in ambient air. Possible PAH sources in road dust include vehicle exhaust, tire, pavement (asphalt or bitumen), and oil spill. PAH concentrations are the highest in areas of traffic followed by urban sites, and lowest in rural sites [2-3]. There are thousands of PAH compounds in the environment but in practice PAH analysis is limited to the 
determination of a few compounds [4-5]. Some main representatives of PAHs are shown in Fig. 1.

PAHs belong to the group of persistent organic pollutants with toxic, carcinogenic and mutagenic properties. Benzo[a]pyrene $(\mathrm{BaP})$ has been identified as an indicator carcinogenic PAH compound [6]. The degree of toxicity and carcinogenicity of PAHs is dependent on the type of compound. PAHs can persist and accumulate in the environment with high risk of bioaccumulation in human and animal tissues, they are largely resistant to biodegradation and can remain in the environment for long periods [7]. The physicochemical properties of PAHs make them highly mobile in the environment, allowing them to spread in air, soil, and water. Atmospheric PAHs can be present in solid or gaseous substances, they are associated predominantly with particulate matters [8].

The aim of this work was to assess the ambient concentrations of PAHs in the PM10 aerosol fraction in an urban site of Györ, Hungary in 2011. This was the first time to comprehensively study the PAH pollution status in the Györ atmosphere. The potential carcinogenic risks of PAHs were also estimated. The levels of carcinogenic PAHs determined in our study were compared with published data of other Hungarian cities.

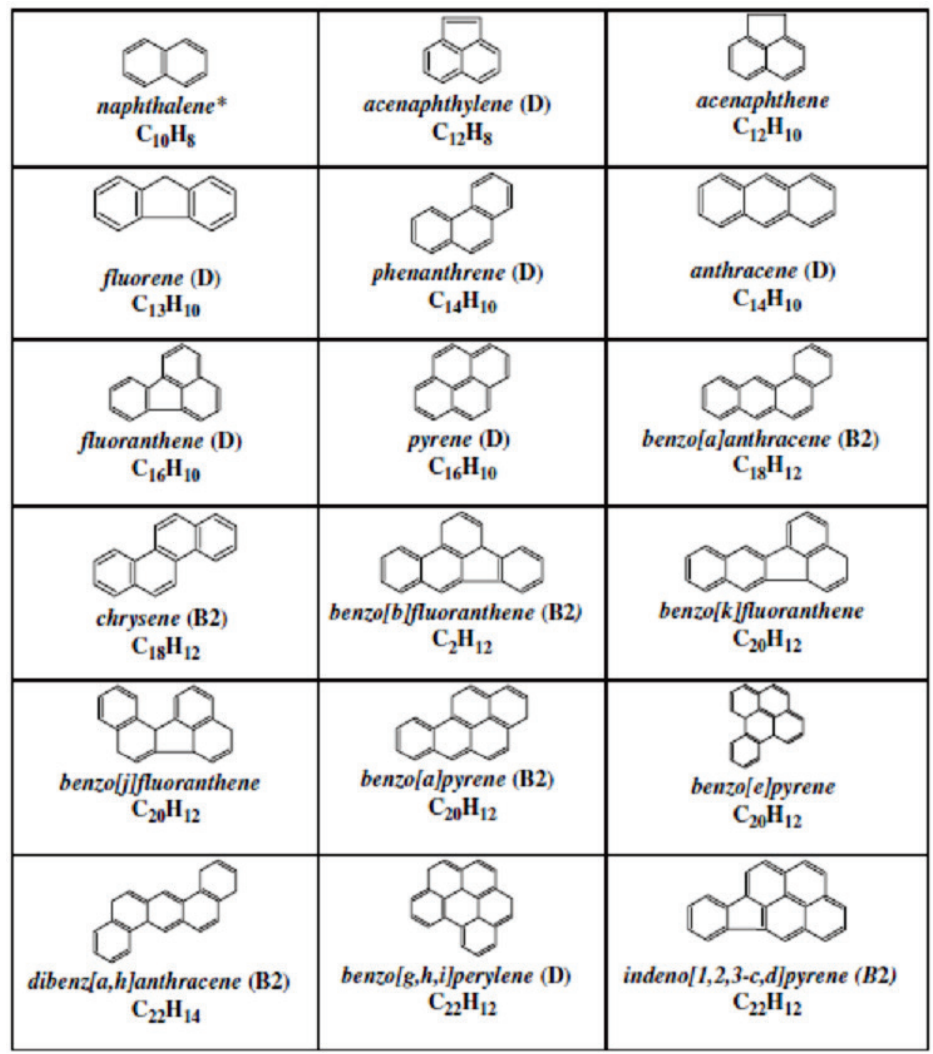

Figure 1. Structure of primary important PAHs [5] (*: not included in priority list; D: not listed as human carcinogen; B2: probable human carcinogen) 


\section{Experimental}

\subsection{Study area}

Györ $\left(47^{\circ} 41^{\prime} 02^{\prime \prime} \mathrm{N}, 17^{\circ} 38^{\prime} 06^{\prime \prime} \mathrm{E}\right)$ is the most important city in the northwest area of Hungary halfway between Wien, Bratislava and Budapest situated on one of the important roads of Central Europe. The city is the sixth largest in Hungary, and one of the seven main regional centres of the country. The location of Györ is shown in Fig. 2. The number of inhabitants is about 128,500 . Györ is a dynamically developing city due to its good geographic situation and as an emphasized centre in automotive industry. It has become one of the largest economic, industrial and traffic areas of Hungary. The monitoring site is located at the junction of Tihanyi Árpád Street and Ifjúság Boulevard, where the main pollution source is the traffic.
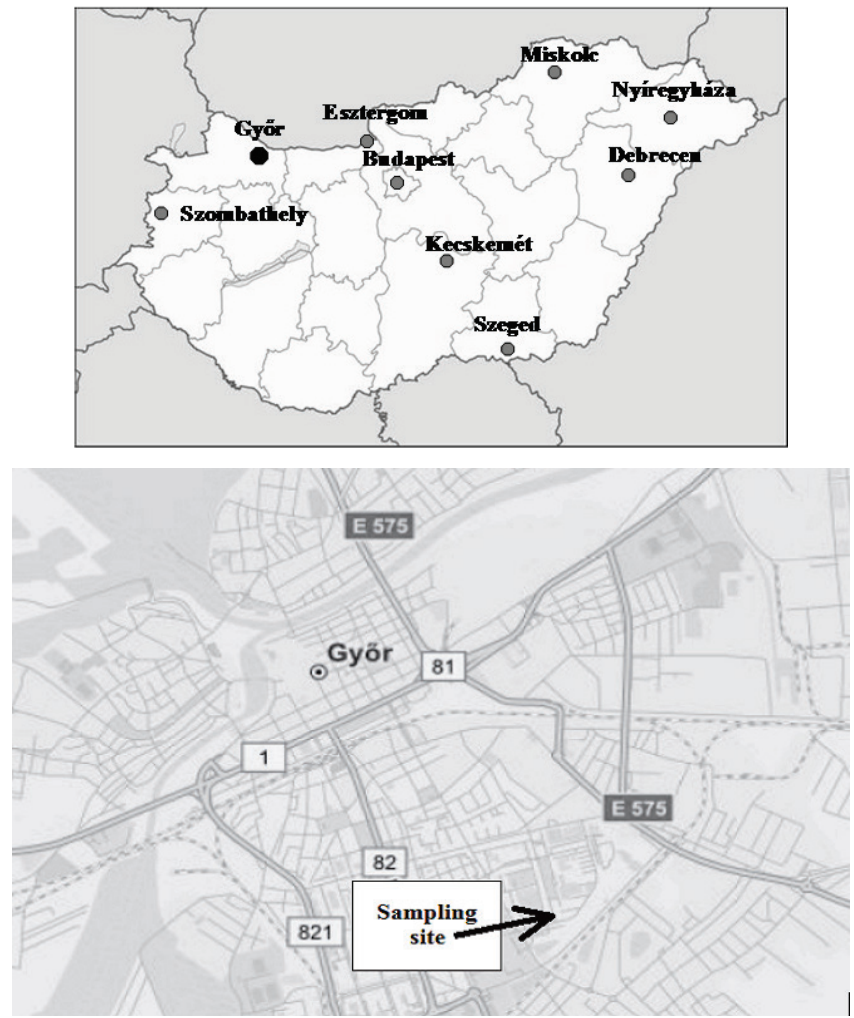

Figure 2. Schematic map of Hungary showing the location of Györ and the sampling site

\subsection{Sampling and chemical analysis}

The concentrations of PM10 aerosol samples were collected in every third month in spring (I.), summer (II.), autumn (III.) and winter (IV.) at 14 day intervals, continuously for 24 hours in 2011 at the monitoring site of Györ. A Digitel High Volume DHA80 
(Digitel Elektronik AG, Switzerland) sampler [9] was used for collection ambient aerosol particles, which were chemically analysed later. This equipment is considered to be equivalent to the requirements of the European Standard (EN 12341) for sampling PM10 matter [10]. In our previous work [11] we described the PM10 sampling, in details.

The ultrasonic liquid-solid extraction of the filter (Advantec QR-100 quartz fibre, $\mathrm{d}=150 \mathrm{~mm}$ ) and the PAH analysis were conducted in accordance with the Hungarian standard method procedure [12]. A gas chromatograph-mass selective detector (GC/MSD) system consisting of an Agilent 6890 gas chromatograph with an Rtx-5MS Integra GC column (30 m long, $0.25 \mathrm{~mm}$ internal diameter, $0.25 \mu \mathrm{m}$ coating, $5 \%$ diphenyl - 95\% dimethyl polysiloxane eluent) and an Agilent 5973 MSD was used in the study. The total PAH concentration was regarded as the sum of the concentrations of 19 measured PAH species for each collected sample.

\section{Results and discussion}

\subsection{Concentration and distribution of PAHs}

Table 1 gives an overview of the concentration ranges, mean values and standard deviations (SD) of the measured PAH compounds associated to PM10 aerosol particles during different sampling periods in 2011, respectively. Fig. 3 shows the average concentrations and SD of total PAHs during the sampling periods.

The total PAH concentrations ranged from $0.88-95.80 \mathrm{ng} / \mathrm{m}^{3}$ with the mean value of $20.06 \mathrm{ng} / \mathrm{m}^{3}$. The levels of total PAHs were relatively higher in heating season (periods I. and IV.) than in spring or summer. Similar to the concentration trend of total PAHs, concentrations of individual PAHs exhibit a large variability during the different sampling periods.

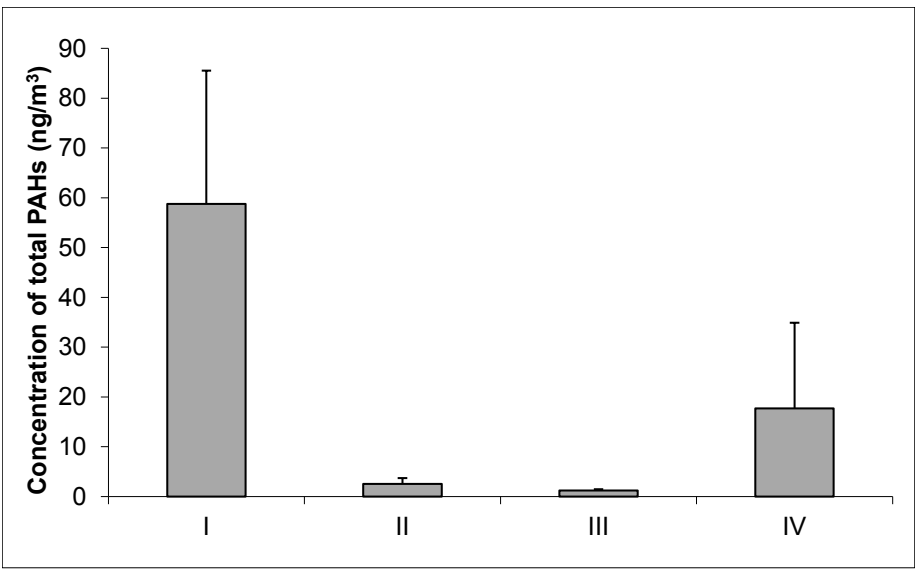

Figure 3. Total PAH concentrations at the urban site of Györ during the four sampling periods in 2011 
Table 1. Concentrations of PAHs in PM10 at the urban site of Györ during different sampling periods in $2011\left(\mathrm{ng} / \mathrm{m}^{3}\right)$

\begin{tabular}{|c|c|c|c|c|}
\hline \multirow[b]{2}{*}{ PAH compound } & \multicolumn{4}{|c|}{ Sampling period } \\
\hline & $\begin{array}{c}\text { I. } \\
16 \text { February- } \\
1 \text { March }\end{array}$ & $\begin{array}{c}\text { II. } \\
4 \text { May- } \\
17 \text { May }\end{array}$ & $\begin{array}{c}\text { III. } \\
1 \text { August- } \\
14 \text { August }\end{array}$ & $\begin{array}{c}\text { IV } \\
1 \text { November- } \\
15 \text { November }\end{array}$ \\
\hline Naphthalene & $\begin{array}{c}0.58-0.90 \\
0.66 \pm 0.09\end{array}$ & $\begin{array}{c}0.11-0.64 \\
0.17 \pm 0.14\end{array}$ & $\begin{array}{c}0.29-0.38 \\
0.34 \pm 0.03\end{array}$ & $\begin{array}{c}0.18-0.31 \\
0.22 \pm 0.03\end{array}$ \\
\hline 2-Methylnaphthalene & $\begin{array}{c}0.35-0.83 \\
0.50 \pm 0.13\end{array}$ & $\begin{array}{c}0.12-0.32 \\
0.16 \pm 0.05\end{array}$ & $\begin{array}{c}0.10-0.19 \\
0.13 \pm 0.02\end{array}$ & $\begin{array}{c}0.04-0.09 \\
0.05 \pm 0.01\end{array}$ \\
\hline Acenaphthylene & $\begin{array}{c}0.03-0.99 \\
0.33 \pm 0.27\end{array}$ & ND & ND & $\begin{array}{c}\text { ND-0.02 } \\
0.00 \pm 0.01\end{array}$ \\
\hline Acenaphthene & $\begin{array}{c}0.02-0.13 \\
0.05 \pm 0.03\end{array}$ & $\begin{array}{c}\text { ND-0.03 } \\
0.00 \pm 0.01\end{array}$ & ND & ND \\
\hline Fluorene & $\begin{array}{c}0.07-0.91 \\
0.34 \pm 0.26\end{array}$ & $\begin{array}{c}0.03-0.09 \\
0.04 \pm 0.02\end{array}$ & $\begin{array}{c}0.03-0.04 \\
0.03 \pm 0.00 \\
\end{array}$ & $\begin{array}{c}\text { ND-0.02 } \\
0.02 \pm 0.01\end{array}$ \\
\hline Phenanthrene & $\begin{array}{c}1.12-7.58 \\
3.89 \pm 2.32\end{array}$ & $\begin{array}{c}0.10-0.28 \\
0.18 \pm 0.06\end{array}$ & $\begin{array}{c}0.09-0.14 \\
0.11 \pm 0.02\end{array}$ & $\begin{array}{c}0.02-0.37 \\
0.13 \pm 0.11\end{array}$ \\
\hline Anthracene & $\begin{array}{c}0.08-0.80 \\
0.32 \pm 0.23\end{array}$ & $\begin{array}{c}\text { ND-0.03 } \\
0.01 \pm 0.01\end{array}$ & $\begin{array}{c}\text { ND-0.02 } \\
0.01 \pm 0.01\end{array}$ & $\begin{array}{c}\text { ND-0.06 } \\
0.02 \pm 0.02\end{array}$ \\
\hline Fluoranthene & $\begin{array}{l}2.04-17.70 \\
9.11 \pm 5.10\end{array}$ & $\begin{array}{c}0.11-0.53 \\
0.25 \pm 0.11\end{array}$ & $\begin{array}{c}0.03-0.09 \\
0.06 \pm 0.02\end{array}$ & $\begin{array}{c}0.28-5.43 \\
1.52 \pm 1.68\end{array}$ \\
\hline Pyrene & $\begin{array}{l}1.59-12.12 \\
6.51 \pm 3.34\end{array}$ & $\begin{array}{c}0.09-0.50 \\
0.21 \pm 0.11\end{array}$ & $\begin{array}{c}0.04-0.09 \\
0.06 \pm 0.02\end{array}$ & $\begin{array}{c}0.40-6.54 \\
1.86 \pm 2.02\end{array}$ \\
\hline Benz[a]anthracene & $\begin{array}{c}0.79-6.19 \\
3.81 \pm 1.86\end{array}$ & $\begin{array}{c}0.03-0.14 \\
0.07 \pm 0.03\end{array}$ & $\begin{array}{c}0.01-0.07 \\
0.03 \pm 0.01\end{array}$ & $\begin{array}{c}0.19-6.99 \\
1.82 \pm 2.24\end{array}$ \\
\hline Chrysene & $\begin{array}{c}1.17-4.62 \\
3.16 \pm 1.22\end{array}$ & $\begin{array}{c}0.08-0.26 \\
0.15 \pm 0.06\end{array}$ & $\begin{array}{c}0.02-0.09 \\
0.05 \pm 0.02\end{array}$ & $\begin{array}{c}0.27-6.72 \\
1.93 \pm 2.10\end{array}$ \\
\hline Benzo[b-k-j]fluoranthene & $\begin{array}{c}3.52-16.39 \\
10.99 \pm 4.40\end{array}$ & $\begin{array}{c}0.25-1.51 \\
0.57 \pm 0.38\end{array}$ & $\begin{array}{c}0.06-0.26 \\
0.14 \pm 0.06\end{array}$ & $\begin{array}{l}0.96-10.41 \\
3.76 \pm 3.33\end{array}$ \\
\hline Benzo[e]pyrene & $\begin{array}{c}2.32-9.15 \\
6.20 \pm 2.35\end{array}$ & $\begin{array}{c}0.11-0.53 \\
0.22 \pm 0.13\end{array}$ & $\begin{array}{c}0.03-0.12 \\
0.07 \pm 0.03\end{array}$ & $\begin{array}{c}0.25-3.06 \\
1.01 \pm 0.89\end{array}$ \\
\hline Benzo[a]pyrene & $\begin{array}{c}0.87-6.86 \\
3.80 \pm 1.90\end{array}$ & $\begin{array}{c}0.03-0.43 \\
0.15 \pm 0.13\end{array}$ & $\begin{array}{c}0.02-0.09 \\
0.04 \pm 0.02\end{array}$ & $\begin{array}{c}0.41-6.92 \\
2.14 \pm 2.09\end{array}$ \\
\hline Indeno[1,2,3-c,d]pyrene & $\begin{array}{c}0.81-7.88 \\
4.71 \pm 2.40\end{array}$ & $\begin{array}{c}0.06-0.45 \\
0.15 \pm 0.12\end{array}$ & $\begin{array}{c}0.03-0.11 \\
0.06 \pm 0.03\end{array}$ & $\begin{array}{c}0.43-5.36 \\
1.77 \pm 1.58\end{array}$ \\
\hline Dibenz[a,h]anthracene & $\begin{array}{c}0.09-0.96 \\
0.51 \pm 0.29\end{array}$ & $\begin{array}{c}\text { ND-0.05 } \\
0.02 \pm 0.02\end{array}$ & $\begin{array}{c}\text { ND-0.07 } \\
0.02 \pm 0.02\end{array}$ & $\begin{array}{c}0.04-0.76 \\
0.22 \pm 0.24\end{array}$ \\
\hline Benzo[g,h,i]perylene & $\begin{array}{c}0.89-6.43 \\
3.88 \pm 1.79\end{array}$ & $\begin{array}{c}0.07-0.52 \\
0.20 \pm 0.13\end{array}$ & $\begin{array}{c}0.03-0.12 \\
0.06 \pm 0.03\end{array}$ & $\begin{array}{c}0.32-3.61 \\
1.21 \pm 1.03\end{array}$ \\
\hline
\end{tabular}

ND: Not detected

The compositional pattern of PAHs is shown in Fig. 4 and 5. Four and five-rings PAHs including fluoranthene (FLT), pyrene (PYR) and sum of the three benzofluoranthene isomers (BbkjF) were the dominant species in the samples. The carcinogenic PAH species (BaP, BbkjF, benz[a]anthracene (BaA), indeno[1,2,3-c,d]pyrene (IND) and dibenz[a,h]anthracene (DahA)) together contributed $43.36 \%$ of the mass of the total PAHs on average. 


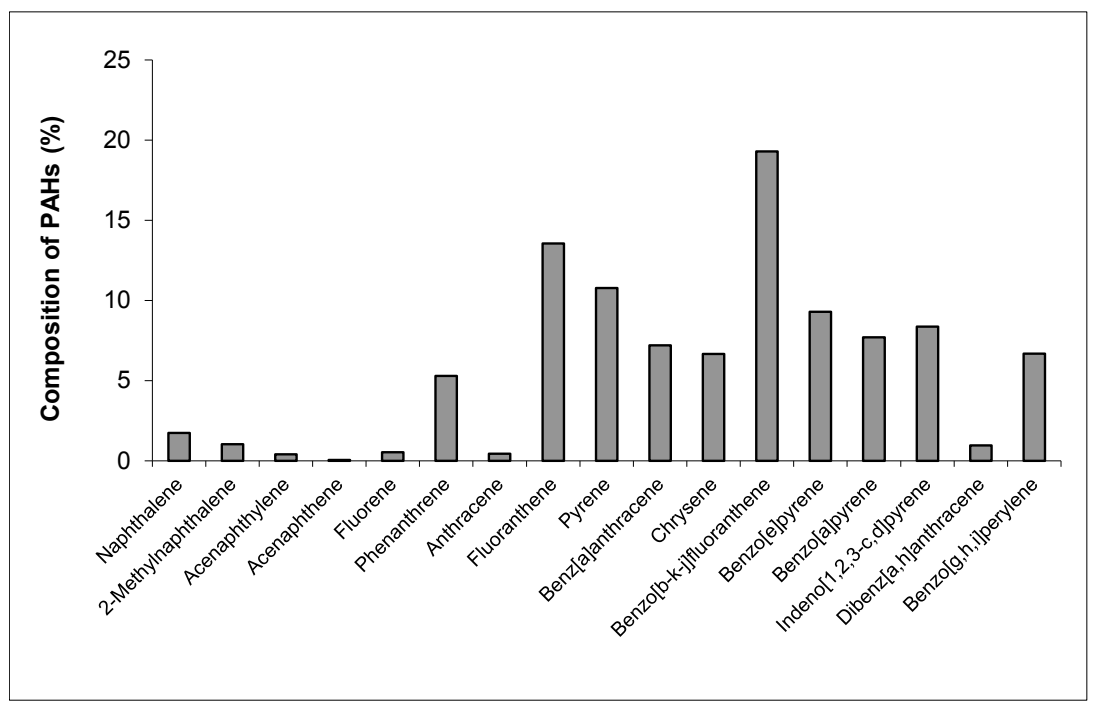

Figure 4. The composition of PAHs measured in Györ in 2011

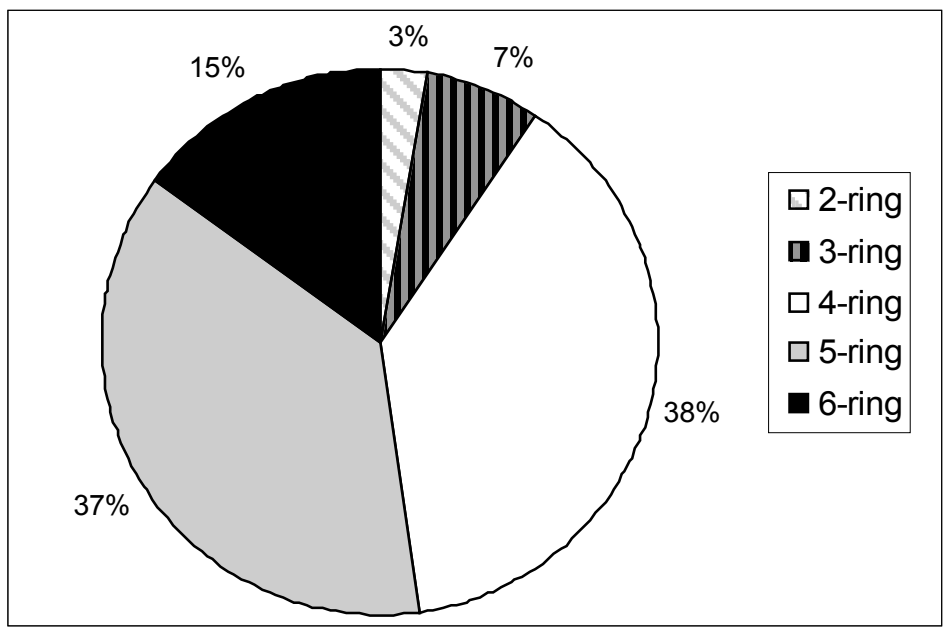

Figure 5. The composition of PAHs based on the number of their constituent benzene rings measured in Györ in 2011

\subsection{Concentration of benzo[a]pyrene}

Among the PAH compounds, only the $\mathrm{BaP}$ concentration is regulated in Hungary and also in EU. The Hungarian daily and annual mean limit values for health protection are 1 $\mathrm{ng} / \mathrm{m}^{3}$ and $0.12 \mathrm{ng} / \mathrm{m}^{3}$, respectively [13]. However, the annual mean target value in the EU legalisation (also in Hungary) is $1 \mathrm{ng} / \mathrm{m}^{3}$ [14]. There is no relevant guideline value for other PAH compounds or total PAHs. The Hungarian air quality index (AQI) can also be used as a reference [15]. It defines air quality categories based on the ratio of pollution (Table 2). 
The BaP concentrations ranged from 0.41 to $6.92 \mathrm{ng} / \mathrm{m}^{3}$ with the mean of $2.97 \mathrm{ng} / \mathrm{m}^{3}$ in heating season, and from 0.02 to $0.43 \mathrm{ng} / \mathrm{m}^{3}$ with the mean of $0.09 \mathrm{ng} / \mathrm{m}^{3}$ in the nonheating season. The annual mean concentration was $1.53 \mathrm{ng} / \mathrm{m}^{3}$, which exceeded the EU target value. However, it was 12.75 times higher than the Hungarian limit value for health protection. The $\mathrm{BaP}$ contamination exceeded the Hungarian daily limit value in $65.52 \%$ of the samples collected in heating season. The comparison of the daily $\mathrm{BaP}$ concentrations with the AQI values show mainly acceptable, polluted or heavily polluted results in heating season, while indicate excellent or good air quality in the non-heating season.

Table 2. Hungarian air quality index for air pollutants as BaP

\begin{tabular}{|c|c|c|c|c|c|}
\hline Category & $\begin{array}{c}\text { 1. } \\
\text { Excellent }\end{array}$ & $\begin{array}{c}\text { 2. } \\
\text { Good }\end{array}$ & $\begin{array}{c}3 . \\
\text { Acceptable }\end{array}$ & $\begin{array}{c}4 . \\
\text { Polluted }\end{array}$ & $\begin{array}{c}5 . \\
\text { Heavily } \\
\text { polluted }\end{array}$ \\
\hline $\begin{array}{c}\text { Related to the } \\
\text { limit value in \% }\end{array}$ & $0-40$ & $40-80$ & $80-100$ & $100-200$ & $200-$ \\
\hline
\end{tabular}

\subsection{Toxicity of PAHs}

$\mathrm{BaP}$ believed to be the most toxic $\mathrm{PAH}$ and it has been well characterized toxicologically. However, less information is available for most of the other PAHs. Several approaches have been developed to obtain a more accurate assessment of potential risk of exposure to a complex mixture of PAHs using toxic equivalency factors (TEFs) based on BaP. The TEF methodology was developed by the U.S. Environmental Protection Agency (EPA) to evaluate the toxicity and assess the risks of a mixture of structurally related chemicals [16]. The TEF for each PAH compound is an estimate of the relative toxicity of the $\mathrm{PAH}$ compound compared to $\mathrm{BaP} . \mathrm{BaP}$ equivalent (BaP-eq) concentration is a useful metric to quantitatively assess the carcinogenic health risk of PAHs [17-18].

The total BaP-eq concentrations based on a number of contributing compounds in the sample can be calculated with the following equation:

$$
\text { Total BaP-eq }=\sum \mathrm{c}_{\mathrm{i}} \cdot \mathrm{TEF}_{\mathrm{i}}
$$

where, $\mathrm{c}_{\mathrm{i}}$ and $\mathrm{TEF}_{\mathrm{i}}$ are the concentration and toxicity equivalency factor of individual PAH compounds, respectively.

In this study TEF values for $14 \mathrm{PAH}$ compounds reported by Larsen and Larsen were used [17]. Table 3 shows the summarized data for the applied TEF approach. BaP-eq was calculated for each component by multiplying the average concentration by its TEF value for each sampling period. The results show that among the analysed PAHs, BaP is the main contributor to the carcinogenicity of the examined PAHs. DaA, IND, FLT and BbkjF also have significant effect in total BaP-eq. The calculated BaP-eq concentration in winter is 25 and 75 times higher than in spring and summer, respectively. 
Table 3. Benzo[a]pyrene equivalent exposure profile in PM10 at the urban site of Györ during different sampling periods in 2011

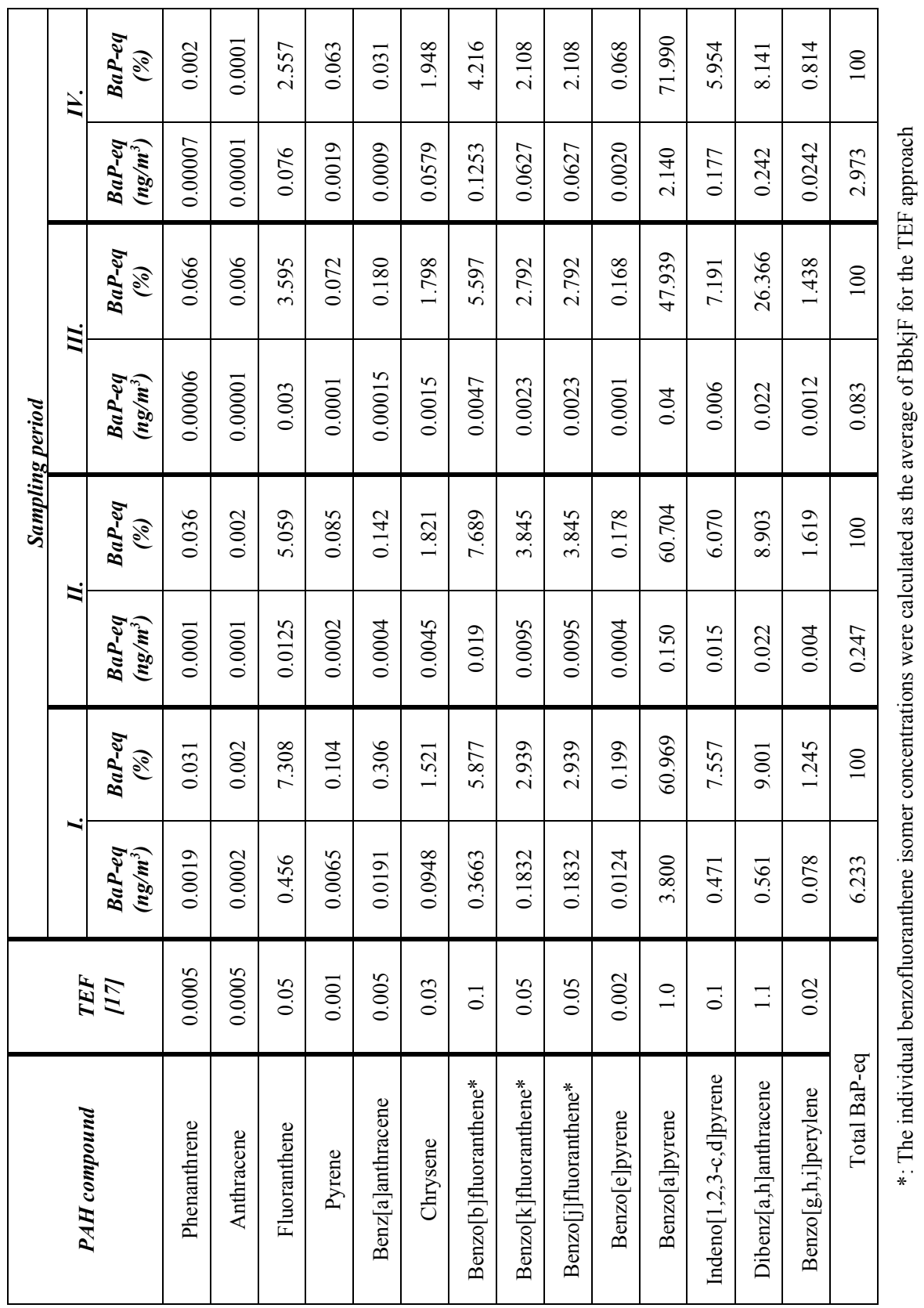




\subsection{Source identification of PAHs}

According to the formation mechanisms, PAHs can be classified as pyrogenic or petrogenic PAHs. Normally, petrogenic PAHs mainly derive from the leakage of crude oil and the refined products such as gasoline, diesel fuel and fuel oil from urban vehicle traffics, whereas the incomplete combustion of diesel/shale/crude oil/coal leads reflects to pyrogenic/combustion origin. Several diagnostic ratios are used to infer the possible sources in environmental samples [5, 19]. PAH isomer pairs have similar physicalchemical properties, thus they have similar dilution and distribution in particulate matter and other environmental phases even though the individual isomers may be characteristic of different sources. The PAH diagnostic ratios used in this study for source identification are summarized in Table 4.

Table 4. PAH diagnostic ratios used as source indicator

\begin{tabular}{|c|c|c|c|c|c|}
\hline \multirow{2}{*}{$\begin{array}{c}\text { Diagnostic } \\
\text { ratio* }^{*} \\
\text { (References) }\end{array}$} & \multirow[t]{2}{*}{ Sources } & \multicolumn{4}{|c|}{$\begin{array}{c}\text { Ranges and mean values of diagnostic ratios in this } \\
\text { study during different sampling periods }\end{array}$} \\
\hline & & I. & II. & III. & $I V$. \\
\hline $\begin{array}{l}\text { FLT/(FLT+PYR }) \\
{[19]}\end{array}$ & $\begin{array}{l}<0.4 \text { Petrogenic } \\
0.4-0.5 \text { Fossil fuel } \\
\text { combustion } \\
>0.5 \text { Grass, wood, coal } \\
\text { combustion }\end{array}$ & $\begin{array}{l}0.53-0.60 \\
0.58\end{array}$ & $\begin{array}{l}0.51-0.59 \\
0.54\end{array}$ & $\begin{array}{l}0.43-0.56 \\
0.50\end{array}$ & $\begin{array}{l}0.16-0.50 \\
0.45\end{array}$ \\
\hline $\begin{array}{c}\mathrm{BaA} /(\mathrm{BaA}+\mathrm{CHR}) \\
{[19]}\end{array}$ & $\begin{array}{l}<0.2 \text { Petrogenic } \\
0.2-0.5 \text { Petrogenic or } \\
\text { combustion } \\
>0.5 \text { Combustion }\end{array}$ & $\begin{array}{l}0.40-0.58 \\
0.52\end{array}$ & $\begin{array}{l}0.25-0.36 \\
0.31\end{array}$ & $\begin{array}{l}0.25-0.44 \\
0.37\end{array}$ & $\begin{array}{l}0.20-0.51 \\
0.44\end{array}$ \\
\hline $\begin{array}{c}\text { IND/(IND+BghiP) } \\
{[5]}\end{array}$ & $\begin{array}{l}0.18 \text { Cars } \\
0.37 \text { Diesel } \\
0.56 \text { Coal } \\
0.62 \text { Wood burning } \\
0.35-0.70 \text { Diesel emission }\end{array}$ & $0.46-0.58$ & $0.35-0.49$ & $0.43-0.50$ & $0.55-0.61$ \\
\hline$[19]$ & $\begin{array}{l}<0.2 \text { Petrogenic } \\
0.2-0.5 \text { Petrogenic or } \\
\text { combustion } \\
>0.5 \text { Grass, wood, coal } \\
\text { combustion }\end{array}$ & 0.54 & 0.42 & 0.47 & 0.59 \\
\hline $\begin{array}{l}\text { FLU/(FLU+PYR) } \\
{[5]}\end{array}$ & $\begin{array}{l}>0.5 \text { Diesel } \\
<0.5 \text { Gasoline }\end{array}$ & $\begin{array}{l}0.02-0.07 \\
0.05\end{array}$ & $\begin{array}{l}0.06-0.28 \\
0.17\end{array}$ & $\begin{array}{l}0.25-0.43 \\
0.37\end{array}$ & $\begin{array}{l}0-0.05 \\
0.02\end{array}$ \\
\hline $\begin{array}{c}\mathrm{BaP} / \text { BghiP } \\
\text { [5] }\end{array}$ & $0.5-0.6$ Traffic & $\begin{array}{l}0.57-1.36 \\
0.99\end{array}$ & $\begin{array}{l}0.32-1.21 \\
0.72\end{array}$ & $\begin{array}{l}0.40-1.0 \\
0.62\end{array}$ & $\begin{array}{l}1.23-2.03 \\
1.58\end{array}$ \\
\hline $\begin{array}{c}\text { FLT/BeP } \\
{[5]}\end{array}$ & $3.5 \pm 0.5$ Automobile exhaust & $\begin{array}{c}0.85-2.01 \\
1.37\end{array}$ & $\begin{array}{c}0.53-1.64 \\
1.25\end{array}$ & $\begin{array}{c}0.56-1.60 \\
0.92\end{array}$ & $\begin{array}{l}0.51-2.13 \\
1.52\end{array}$ \\
\hline $\begin{array}{c}\text { PYR/BeP } \\
{[5]}\end{array}$ & $6 \pm 1$ Automobile exhaust & $\begin{array}{c}0.66-1.38 \\
0.99\end{array}$ & $\begin{array}{c}0.47-1.44 \\
1.03\end{array}$ & $\begin{array}{c}0.50-1.60 \\
0.91\end{array}$ & $\begin{array}{c}0.62-2.41 \\
1.71\end{array}$ \\
\hline
\end{tabular}

${ }^{*}:$ FLT- fluoranthene, PYR- pyrene, BaA- benz[a]anthracene, CHR- chrysene, IND- indeno[1,2,3-c,d]pyrene, BghiPbenzo[g,h,i]perylene, FLU- fluorene, BaP- benzo[a]pyrene, BeP- benzo[e]pyrene 
The results of concentration ratios of FLT/(FLT+PYR) and IND/(IND+benzo[g,h,i]perylene (BghiP)) suggest that the combustion of both liquid and solid fuels was the dominant source of PAH contamination in the Gyor atmosphere. The ratio values of $\mathrm{BaA} /(\mathrm{BaA}+$ chrysene $(\mathrm{CHR}))$ show mainly mixed sources of pyrogenic combustion and petrogenic sources. However, over $80 \%$ of all the samples collected in winter show combustion origins based on the results of $\mathrm{BaA} /(\mathrm{BaA}+\mathrm{CHR})$ diagnostic ratio. The $\mathrm{BaP} / \mathrm{BghiP}$ ratio obtained in this study indicate traffic source over $20 \%$ of all the samples. Vehicular emissions can be derived from gasoline engines based on ratio values of fluorene (FLU)/(FLU+PYR). The IND/(IND+BghiP) ratio values indicate diesel emission. However, the FLT/benzo[e]pyrene (BeP) and PYR/BeP do not indicate automobile exhaust.

Although molecular ratios are often used for characterizing possible pollution sources, their ratios can be altered due to the reactivity of some PAH species with other atmospheric species, such as ozone and/or oxides of nitrogen. In addition to the atmospheric reactivity, degradation that may occur during the sampling process and can also modify the atmospheric PAH levels and thus the ratios between PAHs [5].

\subsection{Comparison with other Hungarian cities}

Fig. 6 illustrates that the annual mean concentration of $\mathrm{BaP}$ observed for Györ is comparable with published data of other Hungarian cities (see also Fig. 2) in 2011 [15]. The $\mathrm{BaP}$ levels almost in all presented cities exceeded the EU target value in 2011. However, the air quality for $\mathrm{BaP}$ in Hungary generally corresponds to the EU average [14]. The exposure value excess is due to the traffic and domestic heating, collectively [14-15].

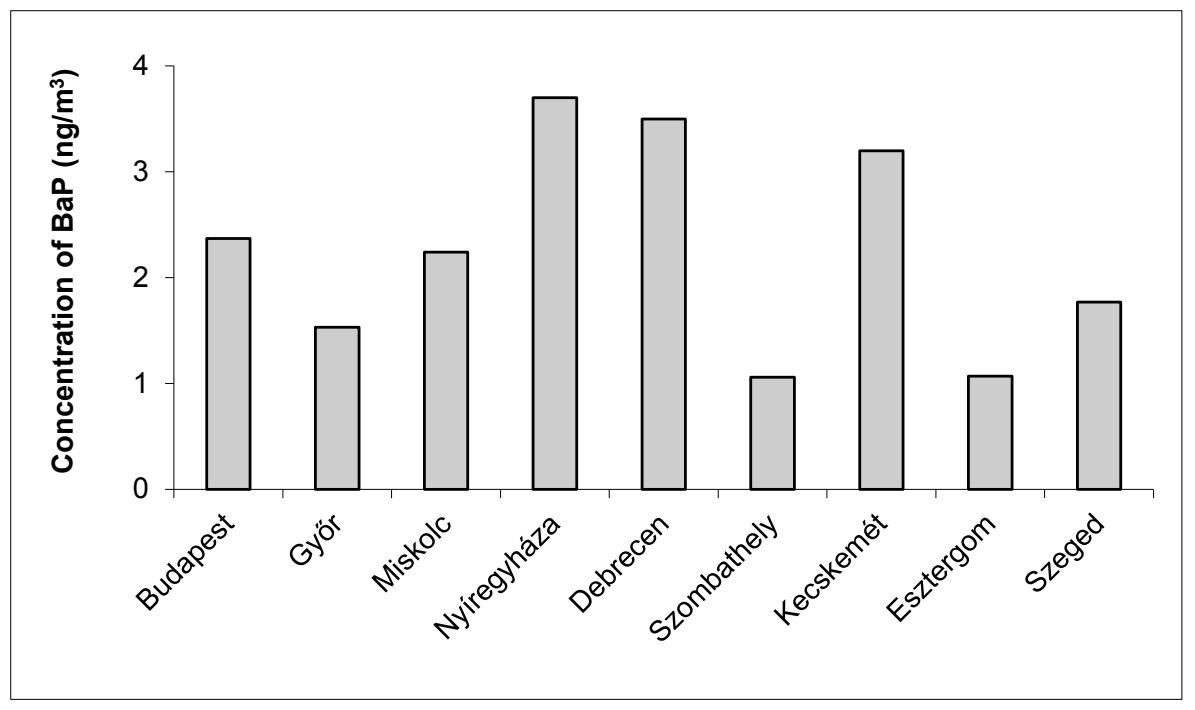

Figure 6. Annual mean concentration of benzo[a]pyrene measured in Györ and other Hungarian cities in 2011 [15] 
The annual mean concentrations of some other carcinogenic PAH species $(\mathrm{BaA}, \mathrm{BbkjF}$, IND and DahA) observed for Győr were also compared with published data of other cities determined under the Hungarian PM10 Monitoring Programme [15]. The data illustrated in Fig. 7 show that the levels of carcinogenic PAHs in Györ PM10 samples were lower than measured in several other Hungarian cities. However, the national air quality database for carcinogenic PAH species is incomplete in some cities. Furthermore, there are no data for total PAHs or other individual PAH compounds. Based on TEF approach reported by Larsen and Larsen [17] on the mean concentrations of carcinogenic PAH species determined at the different Hungarian urban areas, it was found that the three highest carcinogenic exposure were in Nyíregyháza, Debrecen and Kecskemét (Table 5). Similar to the results of Györ, BaP has the highest carcinogenic potency followed by DahA.

In a previous study [20], 13 PAHs could be evaluated quantitatively in PM10 aerosol samples of Budapest (traffic-related site) in the period of 2004-2007. Similar to the results of Györ determined in our study, relatively higher concentrations of PAHs were detected in aerosol samples of Budapest during winter compared with other seasons. The trend is mainly caused by the large seasonal variation in ambient temperature and solar radiation. Additionally, the lower atmospheric mixing height in winter had significant impact on the concentrations of PAHs. The carcinogenic species together contributed 49 $\%$ of the mass of the total PAHs on average. The study has highlighted that the major source of organic compounds in the aerosol of Budapest during the study period was fossil fuel combustion from automobiles. Moreover, the PAH contribution from heating increased in winter.

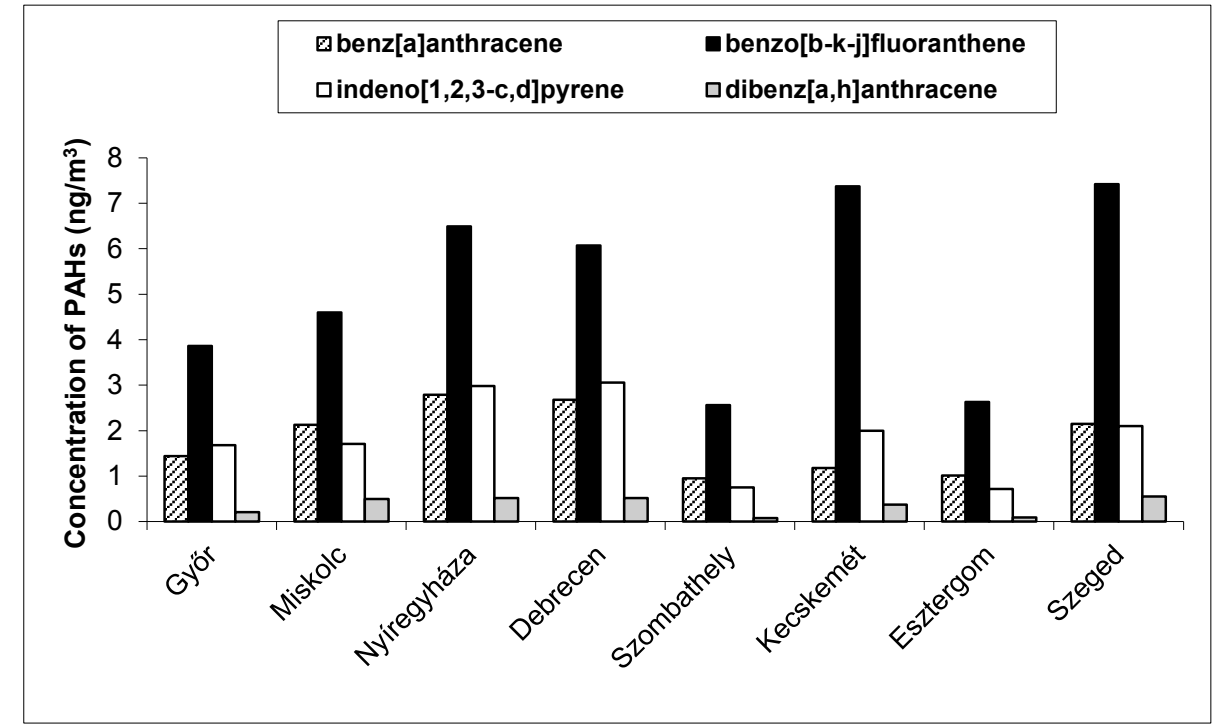

Figure 7. Annual mean concentration of some PAH compounds measured in Györ and other Hungarian cities in 2011 
Table 5. BaP-eq values for the 7 carcinogenic PAH compounds in Györ and other Hungarian cities in 2011

\begin{tabular}{|c|c|c|c|c|c|c|c|c|c|}
\hline \multirow{2}{*}{ Cities } & $\boldsymbol{B a P}$ & $\boldsymbol{B a A}$ & $\boldsymbol{B b F}$ & $\boldsymbol{B k F}$ & $\boldsymbol{B j} \boldsymbol{F}$ & $\boldsymbol{I N D}$ & DahA & Total \\
\cline { 2 - 10 } & \multicolumn{7}{|c|}{$\boldsymbol{B a P - e q ( \boldsymbol { n g } \mathbf { m } ^ { 3 } )}$} \\
\hline Györ & 1.53 & 0.072 & 0.129 & 0.065 & 0.065 & 0.168 & 0.231 & 2.259 \\
\hline Miskolc & 2.24 & 0.107 & 0.153 & 0.077 & 0.077 & 0.171 & 0.550 & 3.374 \\
\hline Nyíregyháza & 3.70 & 0.139 & 0.216 & 0.108 & 0.108 & 0.298 & 0.572 & 5.142 \\
\hline Debrecen & 3.50 & 0.134 & 0.202 & 0.101 & 0.101 & 0.306 & 0.572 & 4.916 \\
\hline Szombathely & 1.06 & 0.048 & 0.085 & 0.0425 & 0.043 & 0.075 & 0.088 & 1.441 \\
\hline Kecskemét & 3.20 & 0.059 & 0.246 & 0.123 & 0.123 & 0.200 & 0.407 & 4.358 \\
\hline Esztergom & 1.07 & 0.051 & 0.088 & 0.044 & 0.044 & 0.072 & 0.099 & 1.468 \\
\hline Szeged & 1.77 & 0.108 & 0.247 & 0.1235 & 0.124 & 0.210 & 0.605 & 3.187 \\
\hline
\end{tabular}

\section{Conclusions}

PM10 aerosol samples were collected and concentrations of 19 individual PAH compounds were determined in an urban site of Györ during four sampling periods in 2011. The levels of total PAHs and the individual PAH compounds exhibit large variability during the sampling periods. The annual average concentration of $\mathrm{BaP}$ was almost 1.5 times higher than the EU target value. Relatively higher concentrations were observed in heating season. Four and five-rings PAHs including FLT, PYR and BbkjF were the dominant species in the samples. Based on calculated BaP-eq concentrations, the results show that different primary individual PAH components have significant environmental impact to $\mathrm{BaP}$-eq. The most important is $\mathrm{BaP}$, which component has the main effect on BaP-eq concentrations.

However, the comparison of the annual mean concentrations of $\mathrm{BaP}$ and other carcinogenic PAHs determined in Györ with other Hungarian cities it was found that the levels of PAHs are relatively low in the Györ atmosphere. Moreover, our results has highlighted that the future Hungarian air quality studies should be focused on source apportionment of PAHs, particularly BaP. Studies on the effect of the meteorological conditions on the PAH concentrations would also be important.

\section{Acknowledgement}

This work was funded by the Széchenyi István University, Hungary. We are obliged to József Erdős, István Vass, Bálint Kauker, Zsuzsanna Károly Némethné, Tünde Takács Kovácsné, Lajosné Bakódy and Péter Lautner (North Transdanubian Regional Environmental Protection and Nature Conservation Inspectorate Laboratory, Hungary) for chemical analyses, data and site information. We also thank József Erdős for field support. 


\section{References}

[1] Kameda T: Atmospheric chemistry of polycyclic aromatic hydrocarbons and related compounds. Journal of Health Science, Vol. 57, No. 6, pp. 504-511, 2011.

[2] Maliszewska-Kordybach, B: Sources, Concentrations, Fate and Effects of Polycyclic Aromatic Hydrocarbons (PAHs) in the Environment. Part A: PAHs in Air, Polish Journal of Environmental Studies, Vol. 8, No. 3, pp. 131-136, 1999.

[3] Hellén H, Hakolaa H, Haaparantaa S, Pietarilaa H, Kauhaniemia M: Influence of residential wood combustion on local air quality. Science of The Total Environment, Vol. 393, pp. 283-290, 2008.

DOI: $10.1016 /$ j.scitotenv.2008.01.019

[4] Kim KH, Jahan SA, Kabir E, Brown RJC: A review of airborne polycyclic aromatic hydrocarbons (PAHs) and their human health effects. Environment International, Vol. 60, pp. 71-80, 2013.

DOI: $10.1016 /$ j.envint.2013.07.019

[5] Ravindra K, Sokhi R, van Grieken R: Atmospheric polycyclic aromatic hydrocarbons: Source attribution, emission factors and regulation. Atmospheric Environment, Vol. 42, No. 13, pp. 2895-2921, 2008.

DOI: $10.1016 /$ j.atmosenv.2007.12.010

[6] Nielsen T, Jorgensen HA, Larsen JC, Poulsen M: City air pollution of polycyclic aromatic hydrocarbons and other mutagens: occurrence, sources and health effects. The Science of the Total Environment, Vol. 189, pp. 41-49, 1996.

DOI: $10.1016 / 0048-9697(96) 05189-3$

[7] Wania F, Mackay D: Tracking the distribution of persistent organic pollutants, Environmental Science and Technology. Vol. 30, No. 9, pp. 390-396, 1996.

DOI: $10.1021 / \mathrm{es} 962399 \mathrm{q}$

[8] Chang KF, Fang GC, Chen JC, Wu YS: Atmospheric polycyclic aromatic hydrocarbons (PAHs) in Asia: A review from 1999 to 2004. Environmental Pollution, Vol. 142, No. 3, pp. 388-396, 2006.

DOI: $10.1016 /$ j.envpol.2005.09.025

[9] Digitel Electronic AG: Digitel high volume aerosol sampler. Manual, Hagenau, Switzerland, 2010.

[10] EN 12341: Air quality - Determination of the PM10 fraction of suspended particulate matter - Reference method and field test procedure to demonstrate reference equivalence of measurement methods. 1998.

[11] Szabó Nagy A, Csanádi Zs, Szabó J: Levels of Selected Metals in Ambient Air PM10 in an Urban Site of Győr, Hungary. Acta Technica Jauriensis, Vol. 7, No. 2, pp. 146-152, 2014.

DOI: 10.14513 /actatechjaur.v7.n2.271

[12] MSZ ISO 12884:2003: Ambient air. Determination of total (gas and partricle-phase) polycyclic aromatic hydrocarbons. Collection on sorbent-basked filters with gas chromatographic/mass spectrometric analyses (in Hungarian).

[13] 4/2011 (I.14.): Guidelines for the air load levels and the stationary point source emissions (in Hungarian).

[14] EEA: Air quality in Europe - 2013 report, European Environment Agency, Luxembourg, 2013. 
[15] OMSZ ÉLFO: Summary of the OLM PM10 sampling program in 2011, Reference Centre for Air Quality Protection, 2012 (in Hungarian).

[16] U.S. EPA: Supplementary Guidance for Conducting Health Risk Assessment of Chemical Mixtures, U.S. Environmental Protection Agency, Washington, DC. EPA/630/R-00/002, August, 2000.

[17] Larsen JC, Larsen PB: Chemical carcinogens, in: Air pollution and health, issues in environmental science and technology. Editors: Hester RE, Harrison RM, The Royal Society of Chemistry, Cambridge, pp. 35-65, 1998.

[18] Boström CE, Gerde P, Hanberg A, Jernström B, Johansson C, Kyrklund T, Rannug A, Törnqvist M, Victorin K, Westerholm R: Cancer risk assessment, indicators, and guidelines for polycyclic aromatic hydrocarbons in the ambient air. Environmental Health Perspectives, Vol. 110, No. 3, pp. 451-488, 2002.

[19] Yunker MB, Macdonald RW, Vingarzan R, Mitchell HR, Goyette D, Sylvestre S: PAHs in the Fraser River basin: a critical appraisal of PAH ratios as indicators of PAH source and composition. Organic Geochemistry, Vol. 33, No. 4, pp. 489-515, 2002.

DOI: $\underline{10.1016 / \mathrm{S} 0146-6380(02) 00002-5}$

[20] Muránszky G, Óvári M, Virág I, Csiba P, Dobai R, Záray Gy: Chemical characterization of $\mathrm{PM}_{10}$ fractions of urban aerosol. Microchemical Journal, Vol. 98, No. 1, pp. 1-10, 2011.

DOI: $\underline{10.1016 / \text { j.microc.2010.10.002 }}$ 